ROCZNIKI NAUK SPOŁECZNYCH

Tom 11(47), numer $4-2019$

DOI: http://dx.doi.org/10.18290/rns.2019.47.4-2

ANNA ŚLIZ

MAREK S. SZCZEPAŃSKI

\title{
KULTUROWE DYLEMATY POLSKIEJ TRANSFORMACJI: MIĘDZY ADAPTACJĄ A ODRZUCENIEM*
}

\section{TRZY DEKADY POLSKIEJ TRANSFORMACJI}

W roku 2019 Polacy są świadkami trzydziestej rocznicy włączenia Polski w światowy system wolności, demokracji i wolnego rynku. Wartości te, a raczej sposób ich realizacji, są przez przedstawicieli rodzimej klasy politycznej wielokrotnie kwestionowane. Ale krytyczna postawa nie towarzyszy wyłącznie klasie politycznej, ale i znacznej grupie intelektualistów, reprezentujących zarówno środowisko naukowe, jak i artystyczne. Wraz z głosami przypominającymi drogę do wolności, wskazującymi zarówno na sukcesy, jak i porażki polskiej transformacji, pojawiają się głosy jednoznacznej negacji tychże osiągnięć. Eksponują one między innymi nierówności społeczne i powiązane $\mathrm{z}$ nimi wykluczenia i - a contrario - uprzywilejowania społeczne. Sukces transformacyjnego trzydziestolecia zamiast więc wzmocnić wspólnotę Polaków raczej pogłębił wewnętrzne animozje. Co ciekawe w tym kontekście: rodzima klasa polityczna nie jest gotowa do wypracowania konsensusu nawet w kluczowych dla Polski sprawach, które wyznaczają pozycję Rzeczpospolitej w systemie światowym. Myślimy tutaj chociażby o ważnej kwestii przyjęcia i pomocy uchodźcom przybywającym na kontynent europejski z terenów objętych działaniami wojennymi -

Prof. dr hab. ANNA ŚLIZ - Szkoła Główna Gospodarstwa Wiejskiego w Warszawie; e-mail: annasliz@op.pl, ORCID iD: https://orcid.org/0000-0001-9112-3409.

Prof. zw. dr hab. MAREK S. SzCZEPAŃSKI - Instytut Socjologii, Uniwersytet Śląski; e-mail: marek.s.szczepanski@us.edu.pl, ORCID iD: https://orcid.org/0000-0002-1084-8211.

* Niektóre fragmenty niniejszego tekstu zaczerpnęliśmy z artykułu: A. ŚLIZ, M.S. SzCZEPAŃSKI, Przeobrażenia kulturowe spoleczeństwa polskiego. Próba bilansu 1989-2014, w: Między wykluczeniem a aktywizacja społeczna. Szkice socjologiczne, red. M.S. Szczepański, P. Rojek-Adamek, Kraków: Oficyna Wydawnicza AFM 2016, s. 11-28. 
Syria czy Irak. Takie aspekty wewnętrznych sporów zmieniają pozytywny wizerunek Polski w świecie, utrwalany $\mathrm{z}$ mozołem od lat 90. ubiegłego wieku. W takich reakcjach RP nie jest odosobniona. Coraz to nowe państwa wspólnoty stawiają głośne veto wobec kolejnych fal ludzi przybywających przede wszystkim z Północnej Afryki. Wzmagają się ruchy nacjonalistyczne. Przykładem jest wygrana w I turze wyborów regionalnych we Francji (6 grudnia 2015 r.) prawicowego Frontu Narodowego Marine Le Pen.

Tytuł prezentowanego artykułu sugeruje, że podejmiemy próbę pokazania drogi przeobrażeń świata kultury społeczeństwa polskiego po roku 1989. Dylematy, które wciąż towarzyszą otwarciu Polski na świat, który charakteryzują różne systemy kulturowe. Mówiąc o kulturze nie unikniemy krótkich, chociażby, peregrynacji w świat ekonomii i polityki. Jesteśmy przekonani, że, między innymi, poziom rozwoju gospodarczego i preferowany przez Polaków światopogląd w poważnym stopniu wyznaczają uczestnictwo i przeobrażenia rodzimych zasobów kulturowych. Skupimy uwagę zarówno na wewnętrznych, jak i zewnętrznych kontekstach kulturowych Rzeczypospolitej. Przypomnimy klasyczne rozumienie kultury, aby kolejno zastanowić się nad jej współczesnymi metamorfozami.

\section{EKONOMICZNE I POLITYCZNE RAMY TRANSFORMACYJNEJ POLSKI}

Polskim przeobrażeniom transformacyjnym od początku towarzyszyła idea budowy społeczeństwa obywatelskiego - Societas Civilis - którego jednym ze znaków był i jest poziom zaangażowania Polaków w oddolne inicjatywy. Zaangażowanie obywatelskie jest monitorowane od 1998 r. W 2017 r. było najwyższe od chwili pomiaru. Jakiekolwiek zaangażowanie obywatelskie w 2017 r. zadeklarowało 48\% Polaków. Najczęściej Polacy angażują się na rzecz potrzebujących dzieci - wzrost z 1,2\% w 1998 r. do 11,0\% w 2017 r., a także wszystkich osób potrzebujących - 1,5\% w 1998 r. i 9,6\% w 2017 r. Dużym zaangażowaniem cieszą się organizacje na rzecz szkolnictwa i oświaty oraz ruchy religijne i wspólnoty parafialne. Spada natomiast zainteresowanie pracą w organizacjach młodzieżowych, związkach zawodowych czy towarzystwach naukowych. Najczęściej Polacy są zaangażowani w pracę jednej organizacji czy stowarzyszenia, ale $14 \%$ angażujących się robi to na rzecz trzech lub więcej organizacji ${ }^{1}$. Ten wzrost zaangażowania jest istotny. Społeczeństwo poświęca czas innym, kiedy

${ }^{1}$ Aktywność Polaków w organizacjach obywatelskich. Komunikat z badań CBOS, Warszawa, luty 2018. 
osiąga wyższy poziom ekonomiczny. Wówczas ludzie bardziej także interesują się kulturą i stają się częstymi jej konsumentami. Rozważania o kulturze poprzedzimy więc wybranymi kwestiami związanymi z ekonomią i polityką.

Idea rozwoju Polski to określone drogi zmian regionów, których ścieżki i tempo przeobrażeń są zróżnicowane. Zmiany w regionach pokazują w konsekwencji tempo przeobrażeń gospodarki krajowej. Wskazujemy na ważność regionów, gdyż trudno uznać za słuszne twierdzenie - odwołujące się do słów przedstawicieli koncepcji modernizacyjnych ${ }^{2}$ - że każdy region musi powielać tę samą linię rozwojową. Poszczególne regiony różnią się przecież między innymi poziomem samoświadomości obywateli i władzy, mentalnością obywateli, systemami aksjologicznymi, normatywnymi czy ideologicznymi, a w końcu rodzajem i poziomem zasobów naturalnych. Regionalną współczesność Polski charakteryzuje stały proces społecznego unowocześniania, zorganizowany zarówno w makroskali (naród, państwo, system światowy), jak i w mikroskali - społeczności lokalne, małe zbiorowości terytorialne ${ }^{3}$. Równocześnie należy pamiętać, że rozwojowemu optymizmowi wobec polskich regionów musi towarzyszyć świadomość, iż zbyt niski wciąż poziom rozwoju Polski ${ }^{4}$ nie musi stanowić naturalnego i imperatywnego stadium marszu ku nowoczesności, ale może stanowić trudną do przezwyciężenia, wielowiekową schedę historyczną, w sposób zasadniczy utrudniający ziszczenie rozwojowych aspiracji. Te trudności można dostrzec chociażby w uproszczonej wizji dychotomicznej Polski, utrwalonej w literaturze przedmiotu jako podział na regiony bliższe standardom cywilizacyjnym Europy Zachodniej i regiony usytuowane na wschód od osi Wisły. To także nawiązanie do dzieła Astolphe'a de Custine'a, arystokraty francuskiego i wysłannika na dwór cara Mikołaja I. W opus magnum, czyli w Listach z Rosji

${ }^{2}$ K. KRZYSZTOFEK, M.S. SzCZEPAŃSKI, Zrozumieć rozwój. Od społeczeństw tradycyjnych do informacyjnych, Katowice: Wydawnicwo Uniwersytetu Śląskiego 2005, s. 55-97; A.W. JELONEK, K. TyszKA, Koncepcje rozwoju społecznego, Warszawa: Wydawnictwo Naukowe Scholar 2001, s. 59-93.

${ }^{3}$ D. Lerner, W. SChramm, Communication and Change in Developing Countries; the last 10 years and next, Honolulu: University Press of Hawaii 1976.

${ }^{4}$ Zacofanie Polski utrwalone historycznie i podlegające regułom dtugiego trwania, przejawiało się - przynajmniej od XVII stulecia - w wyraźnym i jednostronnym dostosowaniu gospodarki do potrzeb zgłaszanych przez przodujące państwa, regiony i miasta Europy (Anglia, Holandia, miasta hanzeatyckie). Wyrażało się również w zbyt wolnym tempie powstawania nowych klas, które organizować mogły wzrost i rozwój gospodarczy, a zatem i przełamać monokulturową gospodarkę i ubogi asortymentowo eksport towarów (zboże, drewno, konopie, dziegieć). Już w XVII wieku Polska była zatem - gdyby użyć współczesnej terminologii - państwem neokolonialnym. M.S. SzCZEPAŃSKi, Pokusy nowoczesności. Polskie dylematy rozwojowe, Kraków-Katowice: Amp 1992. 
napisał, że „Syberia zaczyna się od Wisły”. Nawiązujemy do tej metafory, mając świadomość, że współczesne procesy globalne ten dychotomiczny podział wyraźnie skomplikowały. Utrwalone na kartach literatury nierówności, sięgające czasów rozbiorów, a później realnego socjalizmu, nakładają się na nowe - transformacyjnej proweniencji. Jednocześnie są one naturalnym zjawiskiem w większości krajów Europy, jak również świata. Najważniejsze jednak, aby różnice te nie rodziły wojen, nieprzezwyciężalnych konfliktów i animozji społecznych.

Świadomi różnic w poziomie rozwoju polskich regionów skupimy uwagę także na wybranych wskaźnikach odnośnie do Polski ${ }^{6}$. I już na początku zaznaczmy, że w 2018 r. Rzeczypospolita odnotowała wzrost PBK o 5,1\% wobec 4,8\% w 2017 r. $^{7}$ Ale to w 2017 r. Polska osiągnęła 70\% średniej unijnej pod względem poziomu PKB na mieszkańca - 11,8 tys. euro. Daje to RP wciąż odległe, 24 miejsce wśród 28 państw Unii. Znacznie wyprzedzają nas chociażby Czechy czy Słowacja ${ }^{8}$. Nie jest to sukces, ale cieszy, że poziom życia Polaków wzrasta, chociaż wzrost ten nie rozkłada się równomiernie. Wskazuje na to chociażby poziom PKB polskich regionów wobec unijnej średniej. Wyłącznie Mazowsze przekracza nieznacznie tę średnią (109\%). Pozostałe regiony są poniżej, ale najlepiej prezentują się: Dolny Śląsk 75\%, Wielkopolska 75\% i województwo śląskie $71 \%$. Równocześnie pięć województw osiąga poziom poniżej 50\% średniej unijnej (lubelskie, podlaskie, warmińsko-mazurskie, podkarpackie i świętokrzyskie $)^{9}$. Są to dane wysoko niepokojące, tym bardziej że tempo doganiania Unii słabnie. Lepiej prezentuje się Polska, kiedy uwzględnimy poziom wskaźnika Human Development Index (HDI), na który to poziom składają się: a. średnia długość życia w chwili urodzenia, b. spodziewana liczba lat nauki, c. liczba lat edukacji otrzymanej dla mieszkańców w wieku 25 lat i starszych, d. dochód narodowy per capita. Raport opracowany przez Program Narodów Zjednoczonych ds. Rozwoju za rok 2018 lokował Polskę na 33 miejscu (wartość HDI 0,865) wśród 189 państw. Ważne, że Polska znalazła się w grupie o bardzo wysokim poziomie rozwoju, do której należy 49 państw świata. Czołowe miejsca przypa-

${ }^{5}$ A. DE Custine, Listy z Rosji. Rosja w 1839 roku, tłum. M. Leśniewska, Łódź: Editions Spotkania 2015, s. 111.

${ }^{6}$ Dane, które będziemy przywoływać w tekście, pochodzą z różnych źródeł i różnych lat. Nie są bowiem dostępne najnowsze dane, ale wydaje się, że zbliżone czasowo dane rysują ogólny obraz ekonomiczny Polski drugiej dekady XXI wieku.

${ }^{7}$ Doskonały wynik Polski. Nasza gospodarka w 2018 r. przyśpieszyła, ale są rysy na szkle: https://businessinsider.com.pl [dostęp: 24.03.2019].

${ }^{8}$ Gonimy Unię, ale powoli. Poziom PKB na mieszkańca Polski zwiększył się do 11,8 tys. euro: https://www.money.pl [dostęp: 25.03.2019].

9 PKB polskich województw w zestawieniu ze średnią UE: https://www.rp.pl [dostęp: 25.03.2019]. 
dają Norwegii $(0,953)$, Szwajcarii $(0,944)$ oraz Australii $(0,939)$. Ostatnie zaś Sudanowi Południowemu $(0,388)$, Republice Środkowej Afryki $(0,367)$ oraz Nigrowi $(0,354)^{10}$. Pod koniec $2018 \mathrm{r}$. Polska jako pierwszy kraj z byłego bloku sowieckiego dołączyła do 25 najbardziej rozwiniętych gospodarek na świecie, czyli do grupy „rynków rozwiniętych" $"$.

W roku 1990 z inicjatywy United Nations Development Programme (UNDP) został opracowany wskaźnik Local Human Development Index (Lokalny Wskaźnik Rozwoju Społecznego - LHDI), który opisuje poziom rozwoju społecznoekonomicznego kraju. Jest to średnia geometryczna trzech składowych: indeksu zdrowia, indeksu edukacji i indeksu dobrobytu. W praktyce przekłada się to na dane: a. oczekiwana długość życia, b. średnia liczba lat edukacji otrzymanej dla mieszkańców w wieku 25 lat i starszych, c. średnia liczba lat edukacji dla dzieci rozpoczynających kształcenie, d. dochód narodowy per capita. W 2014 r. LHDI został odniesiony do polskich regionów i podregionów. Przybliżając bardzo ogólne konkluzje trzeba powiedzieć, że najbogatsze regiony Polski to te, gdzie zlokalizowane są duże miasta, a najsłabsze są ulokowane we wschodniej i północnej części Polski ${ }^{12}$. Taki podział $\mathrm{w}$ dużym stopniu utwierdza historyczną schedę zróżnicowania regionalnego Polski.

Dla ogólnego obrazu gospodarczego współczesnej Polski można dodać, że stopa bezrobocia rejestrowanego w styczniu 2019 r. wyniosła 6,1\%. Przeciętne miesięczne wynagrodzenie w sektorze przedsiębiorstw w lutym 2019 r. to 4949,42 złote brutto $^{13}$. Z selektywnie przytoczonych danych wynika, że gospodarka polska wciąż się rozwija, chociaż dystans do większości krajów Unii Europejskiej wciąż jest znaczący. Nie znikają różnice regionalne w poziomie rozwoju i życia. Nie znikają także różnice w poglądach politycznych i świadomościowych Polaków, które w znaczącym stopniu korespondują z poziomem rozwoju ekonomicznego. Regiony silniej rozwinięte stanowią centra życia kulturalnego, a dominującym światopoglądem wśród mieszkańców jest liberalizm i idee centrowe (centrolewica i centroprawica). Takie poglądy polityczne dominują wśród mieszkańców większości dużych i średnich miast Polski. Pokazały to wybory samorządowe 2018 r. Pozostałe regiony Polski głosowały bardziej na partie prawicowe o konserwatywnych programach. Należy jednak podkreślić, że

\footnotetext{
${ }^{10}$ Human Development Reports: hdr.undp.org/en/2018_update [dostęp: 25.03.2019].

11 Polska awansowała do grupy 25 krajów najbardziej rozwiniętych na świecie: https://www.polishexpress.co.uk [dostęp: 26.03.2019].

12 I. LASKOWSKA, B. DAŃSKA-BORSIAK, Analiza przestrzennego zróżnicowania rozwoju spotecznego w Polsce na poziomie NUTS 3 z wykorzystaniem lokalnego indeksu HDI, „Acta Universitatis Lodziensis", Folia Oeconomica 2018, nr 1(333), s. 111-131.

${ }^{13} \mathrm{https} / / /$ stat.gov.pl/podstawowe_dane/ [dostęp: 25.03.2019].
} 
w poglądach politycznych nie ma już jednoznacznego podziału, chociaż wciąż we wschodnich regionach Polski dominują poglądy prawicowe. Zachodnia Polska jest zaś bardziej liberalna i centrowa. W zasadzie najbardziej przewidywalni politycznie są mieszkańcy dużych miast. Jesteśmy świadomi zaprezentowania uproszczonego obrazu świata ekonomicznego i politycznego Polski, ale potraktowaliśmy ten fragment jako wprowadzenie do prezentacji przeobrażeń kulturowych Polski, jakie rozpoczęły się w 1989 r. i wciąż trwają.

\section{PRZEOBRAŻENIA KULTUROWE WSPÓŁCZESNYCH SPOŁECZEŃSTW}

Zainteresowanie kulturą konkretnych społeczeństw towarzyszy analizom socjologicznym od narodzin dyscypliny. Jednocześnie samo zjawisko kultury odnotowujemy wraz z momentem pojawienia się człowieka, ponieważ to właśnie człowiek jest podmiotem kształtowania świata kultury. Pierwsze refleksje nad kulturą towarzyszyły już starożytnym filozofom, z nich ważniejsza rola przypisywana jest Markowi Tulliuszowi Cyceronowi, który pojęcie kultury wprowadził do świata nauki i które zrobiło karierę w kulturze europejskiej. System kultury europejskiej rościł sobie wówczas prawo do opanowania wszystkich kontynentów. Sprzyjał temu czas europejskiej kolonizacji, przy czym nie chodzi tutaj wyłącznie o zawłaszczania terytorialne przez Europejczyków, ale o narzucanie poglądu o niższości danej kultury w stosunku do kultury europejskiej, co mogło, ale nie musiało iść $\mathrm{w}$ parze $\mathrm{z}$ podbojem ziem, na których dana kultura miała swe korzenie i swe siedlisko ${ }^{14}$. Odniósł się do tego Clifford Geertz: „,...] kultura oznacza po prostu Zachód, tę swojego rodzaju jedyną racjonalną, historyczną, rozwojową i «nabożną» całość. Zachód to centrum świadomej myśli i królestwo poznania, które stają naprzeciw ogromu świata peryferii jako całości opartej na przesądach, statycznej, archaicznej i przesyconej magią, słowem - antytetycznego «tam» wobec racjonalnego «tutaj»" 15 . To idea europocentryzmu, która w prostej postaci obowiązywała do Oświecenia, kiedy dostrzeżono różnorodność kultur i wprowadzono idee relatywizmu kulturowego.

Przełom XIX i XX wieku przyniósł radykalną zmianę w postrzeganiu różnic kulturowych. „To nie ewolucja i jej prawa, ale kultura tłumaczy zróżnicowanie obyczajów, stylu życia, praktyk seksualnych i form wierzeń religijnych. Rodzi

${ }^{14} \mathrm{~K}$. WILKOSZEWSKA, Ku estetyce transkulturowej. Wprowadzenie, w: Estetyka transkulturo$w a$, red. K. Wilkoszewska, Kraków: Universitas 2004, s. 10.

15 C. GeErTZ, After the Fact. Two Countries, Four Decades, One Anthropologist, Cambridge, Mass.: Harvard University Press 1995, s. 42-43. 
się «kultura jako ideologia intelektualistów», mnożyć się poczynają w konsekwencji konkurencyjne wobec siebie teorie kultury"16. Ideologia kultury dostrzega kulturowe zróżnicowanie świata, powszechność kultury, a także ich równość. Kultura stała się jednym z najczęściej podejmowanych zagadnień w świecie nauki. Świadczy o tym między innymi fakt, że dzisiaj dysponujemy ponad 200 definicjami kultury. Różniąc się zakresowo, krzyżując się i nakładając na siebie, mają jedną cechę wspólną: ,[...] wyodrębniają kulturę jako byt autonomiczny, samoistny, całościowy i funkcjonujący na poziomie teoretycznym w sposób analogiczny, pomimo konkretnych empirycznych wariantów kultur zmiennych w czasie i rozrzuconych w przestrzeni" ${ }^{17}$. Wszelkim zbiorowościom reprezentującym sobie przypisany styl życia, nałożono gorset kulturowy jako ich podstawowy wyróżnik. Tymczasem antropologia powiada: „,...] świat to wielość kultur, ich bogactwo i odmienność" ${ }^{18}$. Wyodrębnione kultury stawały się dla swoich członków jedyną rzeczywistością, w której przebiegał ich proces socjalizacji. Taka rzeczywistość dominowała w czasach względnej izolacji małych wspólnot. Dzisiaj to nie izolacja, ale świat mieszania się wielu kultur na jednym terytorium staje się rzeczywistością dominującą. To świat nie do końca poddający się jakiejkolwiek naukowej kontroli, a jego cechę stanowi to, że jest on faktem, którego nie da się ani powstrzymać, ani tym bardziej cofnąć ${ }^{19}$.

Dzisiaj kultura stała się ważnym elementem rozwoju społecznego. To kultury rozwojowe, o których pisał Zygmunt Bauman. Są to kultury wymagające rosnącej ilości energii i pobudzające wzrost jej absorpcji. To przeciwny kraniec kultur stabilnych, które wymagały stałej ilości energii i przeciwdziałające jej powiększaniu $^{20}$. W granicach współczesnych społeczeństw krzyżują się rozmaite perspektywy kulturowe, co przeczy istnieniu kultury jako systemu, ale staje się wypadkową mnóstwa niepowtarzalnych kontaktów kulturowych ${ }^{21}$. Kultura nie jest dzisiaj raz na zawsze danym systemem, ale podlega ciągłej ewolucji, będącej efektem przenikania się wielu różnych kultur w określonej przestrzeni społecznej.

W system zróżnicowanego kulturowo świata prawie trzy dekady temu została włączona Polska, która stanęła w obliczu konieczności przewartościowania

${ }^{16}$ W. BurszTa, Wielokulturowość. Pytania pierwsze, w: U progu wielokulturowości. Nowe oblicza społeczeństwa polskiego, red. M. Kempny, A. Kapciak, S. Łodziński, Warszawa: Oficyna Naukowa 1997, s. 24.

17 Tamże, s. 26.

18 Tamże, s. 27.

${ }^{19}$ Z. Bauman, Globalizacja. I co z tego dla ludzi wynika, Warszawa: PIW 2000, s. 5.

${ }^{20}$ Z. BAuman, Szkice z teorii kultury, Warszawa: Wydawnictwo Naukowe Scholar 2017, s. 59.

${ }^{21}$ D. BRZEZIŃSKI, Redukcja i proliferacja wieloznaczności teorii kultury Zygmunta Baumana w polskim okresie jego twórczości, „Studia Socjologiczne” 2017, nr 1(224), s. 44. 
utrwalanej, szczególnie w okresie realnego socjalizmu, wizji świata monokulturowego. W tym momencie nasuwa się krótka dygresja odnośnie do postaw władz Polski i Polaków wobec problemu uchodźców na kontynencie europejskim. Deklarowana niechęć wielu Polaków wobec przybyszów z odrębnego kręgu kulturowego, wraz z wieloma wręcz absurdalnymi argumentami, wynika w dużej mierze właśnie z ideologii lat minionych. Różnorodność kulturowa nie była bowiem codziennością Polaków po II wojnie światowej, jak miało to miejsce w państwach Europy Zachodniej. Stąd tak wielki dylemat, a także lęk, które towarzyszą rodakom stojącym przed perspektywą włączenia kulturowej różnorodności w codzienne życie. Dzisiaj już wiemy, że postawa niechęci wobec uchodźców, a konkretnie rzecz ujmując: chodzi przede wszystkim o migrantów, z dużą siłą rozprzestrzenia się w wielu państwach zachodniej Europy, ale także Ameryki Północnej. Jak podkreśla wielu analityków współczesności, nawet społeczeństwo niemieckie pozytywnie nastawione do imigrantów przez wiele lat zaczyna stawiać opór wobec napływowi kolejnych ich fal.

Polska, stając się elementem systemu światowego, została poddana przeobrażeniom kulturowym charakteryzującym większość współczesnych społeczeństw. To między innymi pogłębiający się stopień kulturowego zróżnicowania i włączanie go w codzienne funkcjonowanie społeczeństwa. Do problemu, w polskiej socjologii, odniósł się między innymi Andrzej Sadowski, który poddał pod rozwagę odpowiadający problemowi schemat. Autor przyjął, że społeczeństwa ewaluują od zróżnicowanego kulturowo poprzez społeczeństwo pluralistyczne do społeczeństwa wielokulturowego. Tym samym pojawił się prymat układów kulturowych nad politycznymi ${ }^{22}$. Ale pomimo wszelkich przeobrażeń w państwach Europy Środkowo-Wschodniej, a więc także w Polsce, realizowane są przede wszystkim zadania dominującego w przestrzeni narodu etnicznego i w różnym stopniu utrzymywany jest dystans wobec mniejszości narodowych. Preferowane są więc interesy etnicznego państwa narodowego ${ }^{23}$. Tymczasem naród pluralistyczny staje się bardziej narodem politycznym, ponieważ łączy zróżnicowanie kulturowe mieszkańców „w coraz bardziej powiązane wewnętrznie systemy współdziałania, równowagi i rozwoju za sprawą orientacji na realizację wspólnych celów" 24 .

Narody etniczne wskutek procesów globalnych w różnym stopniu otwierają się na imigrantów z odmiennych systemów kulturowych, ale równocześnie dążą

\footnotetext{
22 A. SADOwSKI, Zróżnicowanie kulturowe a społeczeństwo obywatelskie, „Sprawy Narodowościowe" 1999, nr 14-15, s. 33.

${ }^{23}$ A. SADOwSKI, Pochodzenie etniczne a tożsamości narodowe. Narody pluralistyczne na przykładzie Europy Środkowo-Wschodniej, „Kultura i Społeczeństwo” 62(2018), nr 2, s. 137.

${ }^{24}$ Tamże, s. 138.
} 
do zachowania tożsamości narodowej. Chcą zachować dominujący status kultury narodowej. W państwach pluralistycznych utrzymanie takiego statusu jest bardzo trudne. Współczesna Polska to wciąż dominująca pozycja narodu etnicznego, chociaż społeczeństwo można określić jako zróżnicowane kulturowo, czyli takie, gdzie zamieszkują dwie lub więcej grup lub kategorii kulturowych oraz stworzone są warunki ku temu, aby każda $\mathrm{z}$ nich w jakiś sposób mogła podtrzymywać swoje wartości kulturowe. Nie zawsze zróżnicowanie kulturowe jest widoczną cechą społeczeństwa i uzewnętrznia się ono dopiero w procesach narastania sfery wolności i demokracji. Tak właśnie było w Polsce. Ukrywane różnice kulturowe w okresie realnego socjalizmu z wrodzoną sobie siłą ujawniły się po roku 1989, włączając Polskę w ogólnoświatowy system przenikania się kultur między innymi jako efekt rewolucji migracyjnej. Powinniśmy także być świadomi, że zmiany kulturowe współczesnego świata to nie wyłącznie przenikanie i łączenie się kultur, ale także zjawisko opisane przez przedstawicieli teorii zależności, czyli koncepcja gwałtu symbolicznego. Termin zapożyczony od Pierre'a Bourdieu i JeanaClaude'a Passerona ${ }^{25}$ w socjologii zmiany i rozwoju oznacza stale ponawiane próby przekazania państwom słabo rozwiniętym obcych mu systemów ideologicznych i doktrynalnych, szeroko rozumianych wartości i norm oraz instytucji zrodzonych w europejskich i północnoamerykańskich kręgach kulturowych. Gwałt symboliczny może prowadzić do częściowego, a niekiedy i całkowitego zatracenia tożsamości kulturowej ${ }^{26}$. Jest faktem, że Polska przejmuje pewne elementy systemu innych kultur, ale jak dotychczas nie zagrażają one polskiej tożsamości narodowej, chociaż niektórzy takie niebezpieczeństwo są skłonni dostrzegać. Zdecydowanie więcej głosów sprzeciwu wzbudzają przeobrażenia odnoszące się na przykład do rodziny - rozwody czy alternatywne formy życia rodzinnego ${ }^{27}$. To już nie tylko dostrzeganie rzeczywistych różnic kulturowych występujących w rzeczywistości współczesnej Polski, ale niekiedy poważne dylematy, a nawet działania im zapobiegające.

25 P. Bourdieu, J.-C. PASSERon, Reprodukcja. Elementy teorii systemu nauczania, thum. E. Neyman, Warszawa: Wydawnictwo Naukowe PWN 2006.

${ }^{26}$ K. KRZYSZTOFEK, M.S. SZCZEPAŃSKi, Zrozumieć rozwój, s. 117.

${ }^{27} \mathrm{~K}$. SLANY, Alternatywne formy życia matżeńsko-rodzinnego w ponowoczesnym świecie, Kraków: Zakład Wydawniczy Nomos 2002. 


\section{ZRÓŻNICOWANIE KULTUROWE WSPÓŁCZESNEJ POLSKI}

Wspomnieliśmy powyżej, że dzisiejsza Polska to państwo o mniej lub bardziej dostrzegalnym zróżnicowaniu kulturowym. Przed rokiem 1989 polityka ówczesnych władz była odmienna i zmierzała, krótko i prosto rzecz ujmując, w kierunku stworzenia społeczeństwa polskiego jako homogenicznego pod względem kulturowym. W pewnym stopniu polityka ta odniosła sukces, gdyż wciąż społeczeństwo polskie pozostaje względnie monokulturowe, chociaż z dostrzeganymi mniejszościami kulturowymi i etnicznymi. Odnotowujemy więc powolny wzrost różnorodności obywatelskiej wśród mieszkańców Rzeczpospolitej. Trudno jeszcze w tym kontekście odnieść się chociażby do koncepcji Richarda L. Floridy ${ }^{28}$, który wprowadzając Melting Pot Index (indeks różnorodności kulturowej) dowodził, że miasta o wyższym odsetku mniejszości narodowych i etnicznych cechuje wyższa dynamika rozwoju. W Polsce zauważalna jest jedynie wzrastająca liczba przedstawicieli rozmaitych kręgów kulturowych.

Dzisiaj Polskę wciąż charakteryzuje niski udział mniejszości narodowych i etnicznych wśród mieszkańców. Zerwanie z polityką realnego socjalizmu położyło kres ograniczeniom otwartego wyrażania własnej tożsamości. To zjawisko charakterystyczne nie tylko dla Polski, ale i innych państw postkomunistycznych, gdzie ,[...] polityczna liberalizacja występuje ze wzmożonym poczuciem własnej tożsamości narodowej” ${ }^{29}$. Polskiej liberalizacji życia społecznego i politycznego towarzyszy coraz wyraźniejsze włączanie się mniejszości narodowych i etnicznych w sfery życia publicznego, które zwiększa szanse przetrwania i rozwoju własnej kultury. Zamykanie się wyłącznie w sferze prywatnej prowadzi do marginalizacji i zaniku kulturowej odmienności. Warunkiem udziału przedstawicieli mniejszości w życiu publicznym jest ich akceptacja przez dominującą grupę narodowościową, gdyż wówczas tworzy się pożądany stan harmonijnego współistnienia wszystkich obywateli. To jedna z ważniejszych zmian w ramach systemu kultury rodzimego społeczeństwa. Musimy jednak pamiętać, że zarówno starym grupom etnicznym oraz kulturowym, jak i tworzeniu się nowych społeczności imigranckich i o odmiennych systemach aksjologicznych i normatywnych towarzyszą dwie ścierające się postawy polskiego społeczeństwa: postawa tolerancji oraz przeciwna jej postawa dyskryminacji. To jeden z najważniejszych dylematów okresu polskiej transformacji. Nie jest to oczywiście dylemat wyłącznie polski. Dzisiaj wskazany rozdźwięk jest szczególnie

${ }^{28}$ R.K. Florida, Cities and the Creative Class, New York-London: Routledge 2005.

${ }^{29}$ W. KYMLICKA, Multicultural Citizenship. A Liberal Theory of Minority Rights, Oxford: Oxford University Press 1994, s. 77. 
widoczny w konfrontacji z falą uchodźców - przede wszystkim muzułmanów którzy raczej wcześniej niż później będą szukali dla siebie miejsca także w Polsce. Jest to problem o tyle trudny, że ok. 36 milionów mieszkańców Polski deklaruje wyznanie rzymskokatolickie ${ }^{30}$. Trudno więc wielu Polakom zaakceptować w sąsiedztwie wyznawców odmiennych religii, tym bardziej że wokół niektórych $\mathrm{z}$ nich narosło bardzo wiele negatywnych emocji - islam, judaizm. Piszemy o wybranych zjawiskach $\mathrm{w}$ Polsce, ale jesteśmy świadomi, że wszystkie one z różną siłą są obecne w wielu społeczeństwach świata, a szczególnie w Europie i Ameryce Północnej, a ostatnio także w Australii i Nowej Zelandii. Dotyczą one postaw nie tylko wobec zupełnie obcych kulturowo, ale także wszystkich w jakimkolwiek zakresie innych.

Ważniejszym aktorem przeobrażeń w obrazie polskiej kultury są mniejszości narodowe i etniczne, których udział w życiu społecznym sukcesywnie wzrasta, chociaż wciąż jest to raczej udział znikomy. Wyniki Narodowego Spisu Powszechnego Ludności i Mieszkań z $2011 \mathrm{r}^{31}$ to potwierdzają. Zgodnie z nimi 93,9\% ankietowanych zadeklarowało jednolitą polską tożsamość narodową, 2,19\% deklarowało zarówno polską, jak i inną tożsamość narodowo-etniczną, a 1,46\% - tożsamość inną niż polską. Rzeczpospolita jawi się zatem jako kraj niemal jednorodny etnicznie. Należy jednak pamiętać o przedstawicielach czterech mniejszości etnicznych, żyjących w naszym kraju. Są to mniejszości niezwykle barwne, chociaż mało dostrzegalne w społeczeństwie. Karaimi, do których należy 313 polskich obywateli, przybyli na ziemie polskie z Krymu w XIII wieku. Są wyznawcami religii karaimskiej, która wywodzi się z judaizmu. Mieszkają w województwie mazowieckim, łódzkim i dolnośląskim. Łemkowie to 9641 polskich obywateli. Zamieszkują tradycyjnie województwo małopolskie, ale również dolnośląskie i lubuskie. Należą do dwóch kościołów: Polskiego Autokefalicznego Kościoła Prawosławnego i Kościoła Katolickiego obrządku Bizantyńsko-Ukraińskiego. Posiadają język łemkowski, którego w roku szkolnym 2012/2013 uczyło się 281 należących do tej mniejszości. Romowie to 16725 obywateli Polski. Od XV wieku wzdłuż łuku Karpat i od strony Niziny Węgierskiej przybywały do Polski i osiedlały się grupy wędrujących Romów. Są członkami Kościoła Rzymskokatolickiego, a zamieszkują głównie w województwie dolnośląskim, małopolskim i śląskim. Tatarzy to 1828 obywateli polskich, którzy są wyznawcami religii muzułmańskiej. Mieszkali na ziemiach Księstwa Litewskiego od końca XIV wieku. Ich przodkowie byli uciekinierami ze Złotej Ordy

${ }^{30}$ Zob. Wyznania w Polsce, http://www.wsp.krakow.pl/apismo/nr1/01/wyznania.html [dostęp: 17.03.2009].

${ }^{31}$ Raport z wyników Narodowego Spisu Powszechnego Ludności i Mieszkań 2011. Podajemy dane jako łączne niezależne od liczby i kolejności deklaracji; www.stat.gov.pl [dostęp: 14.09.2015]. 
i Krymu ${ }^{32}$. Wraz z mniejszościami etnicznymi odnotowujemy w Polsce także mniejszości narodowe, których jest dziewięć. Najliczniejsza to mniejszość niemiecka (126 tys.). Pozostałe grupy to Białorusini (46 tys.), Czesi (3 tys.), Litwini (8 tys.), Ormianie (3 tys.), Rosjanie (13 tys.), Słowacy (3 tys.), Ukraińcy (49 tys.) oraz Żydzi (7 tys.). Jako pewne novum odnotowujemy 11 tys. deklaracji związanych z identyfikacją amerykańską. Prezentując powyższe dane trudno nie odnotować dwóch najliczniej reprezentowanych grup mniejszościowych na terytorium Polski. Chodzi o Ślązaków - przynależność do tej grupy zadeklarowało łącznie 817 tys. osób, i Kaszubów. Identyfikację z tą drugą grupą wyraziło 229 tys. osób. Przy okazji należy wspomnieć, że język kaszubski uzyskał jako jedyny w Polsce status języka regionalnego. O taki sam status od wielu lat zabiegają przedstawiciele społeczności śląskiej. Wciąż bezskutecznie. Bezskuteczne okazało się także dążenie Ślązaków do uznania ich za mniejszość etniczną.

Okres polskiej transformacji to zarówno czas zasadniczych przemian ustrojowych i gospodarczych, jak również istotne zmiany w polityce wobec mniejszości narodowych i etnicznych. W początkowym okresie transformacji mniejszości walczyły o uzyskanie podmiotowości w tworzącym się ładzie demokratycznym, które $\mathrm{z}$ czasem przechodziły w działalność na rzecz zachowania tożsamości etnicznej. Rezultatem tego aspektu działalności jest chęć manifestowania własnej odrębności kulturowej. Zjawisku temu towarzyszą obserwowane - czasami wśród Polaków postawy narodowego szowinizmu, nietolerancji, ksenofobii i uprzedzeń. Nie bez znaczenia pozostaje rola zakorzenionych w świadomości Polaków stereotypów, które w poważnym stopniu kształtują świadomość rodaków w odniesieniu do niektórych mniejszości - Cyganie (Romowie) czy Żydzi. Równocześnie musimy pamiętać o przeważającej wśród Polaków postawie otwartości i akceptacji wobec różnych mniejszości, a także grup uchodźców czy imigrantów przybywających na terytorium Rzeczpospolitej. Tak sformułowaną tezę potwierdza poziom sympatii i antypatii Polaków w odniesieniu do ,innych”. Największą niechęć odczuwają Polacy wobec mniejszości cygańskiej (romskiej), żydowskiej, ukraińskiej i rosyjskiej. Na przeciwnym krańcu ulokowały się mniejszości obdarzane przez Polaków największą sympatią. Jest to mniejszość słowacka, czeska, litewska, białoruska oraz niemiecka. Postawy niechęci czy dyskryminacji utrudniają, a czasami wręcz uniemożliwiają, właściwe funkcjonowanie przedstawicieli mniejszości, i to zarówno w życiu prywatnym, jak i publicznym czy instytucjonalnym. Zjawisko dyskryminacji przejawia się w rozmaitych formach, jak chociażby stygmatyzacji (piętnowaniu) ${ }^{33}$. Jest to tym

\footnotetext{
${ }^{32}$ Mniejszości etniczne w Polsce [Infografika]: https://wiadomosci.onet.pl/kraj/mniejszoscietniczne-w-polsce/f2x3jx5 [dostęp: 26.03.2019].

${ }^{33}$ E. CZYKwIN, Stygmat społeczny, Warszawa: Wydawnictwo Naukowe PWN 2007.
} 
bardziej trudne, że przywołując Ervinga Goffmana: „Osoby stygmatyzowane to takie, które posiadają społeczny atrybut głęboko je dyskredytujący i które są postrzegane jako niepełnowartościowe z tego właśnie powodu"34. Zrzucenie piętna w tym rozumieniu wydaje się bardzo trudne, jeśli w ogólne możliwe.

Włączenie mniejszości narodowych i etnicznych w kształtowanie rzeczywistości Polski po 1989 r. zyskało regulację prawną w postaci Ustawy o mniejszościach narodowych $i$ etnicznych oraz o języku regionalnym $z$ dnia 6 stycznia 2005 roku ${ }^{35}$. Ustawa ta w sposób szczegółowy reguluje sprawy związane z zachowaniem i rozwojem tożsamości kulturowej mniejszości narodowych i etnicznych oraz zachowaniem i rozwojem języka regionalnego, a także sposób realizacji zasady równego traktowania osób bez względu na pochodzenie etniczne. Określa zadania i kompetencje organów administracji rządowej i jednostek samorządu terytorialnego w zakresie tych spraw. Należy jednak jasno powiedzieć, że nie zawsze przepisy te są wdrażane w życie i skutecznie ochraniają przedstawicieli mniejszości. Stosunek Polaków do nich jest także wyraźnie zróżnicowany. Istnieje szansa, że wzajemne relacje będą się zmieniały, chociażby ze względu na coraz bardziej obecną w publicznej przestrzeni kulturową różnorodność. Jej przejawem jest choćby fakt tworzenia przez imigrantów, a często także ich polskich przyjaciół, stowarzyszeń i organizacji, które podejmują inicjatywę nastawioną na adaptację do polskiej rzeczywistości. Przykładem mogą być organizacje: Stowarzyszenie Uchodźców w Polsce czy Stowarzyszenie Małżeństw Polaków z Cudzoziemcami. Ponadto organizowane są święta i imprezy propagujące różne kultury. Są to przykładowo pokazy Samby na Nowym Świecie w Warszawie, Dzień Jedności Afrykańskiej czy Wielokulturowe Street Party ${ }^{36}$. Nowi imigranci najczęściej żyją w rozproszeniu, adaptując się powoli do polskiej rzeczywistości, ale równocześnie nie zapominając o własnym dziedzictwie kulturowym.

W powyższym fragmencie staraliśmy się pokazać sytuację imigrantów, mniejszości narodowych i etnicznych zamieszkałych w Polsce i wobec nich postawę Polaków. Wydaje się, że nie odbiega ona w znaczący sposób od zachowań wszystkich innych ludzi - tak jak wiele społeczeństw, Polacy przejawiają zarówno pozytywne, jak i negatywne postawy wobec ,innych”, a i polityka polskich władz w takich właśnie ramach się mieści.

${ }^{34}$ E. Goffman, Piętno. Rozważania o zranionej tożsamości, thum. A. Dzierżyński, J. TokarskaBakir, Gdańsk: Gdańskie Wydawnictwo Psychologiczne 2005, s. 3.

${ }^{35}$ Ustawa z dnia 6 stycznia 2005 r. o mniejszościach narodowych i etnicznych oraz o języku regionalnym, Dz.U. 2005, Nr 17, poz. 141; Dz.U. 2005, Nr 64, poz. 550: http://e-prawnik.pl/kodeksy/ ustawy/ustawa-o-mniejszościach-narodowych... [dostęp: 14.09.2015].

${ }^{36}$ www.agenda21.waw.pl [dostęp: 30.12.2010]. 


\section{POLSKA KULTURA WOBEC SYSTEMU ŚWIATOWEGO}

Z chwilą otwarcia się na świat zewnętrzny do Polski zaczęły przenikać różnorodne wzory kulturowe, które są w mniejszym bądź większym stopniu akceptowane, albo odrzucane. Ważny jest także kontakt z kulturami odmiennymi, które są obecne w polskiej rzeczywistości. Elementy tych kultur w pewnym stopniu wzbogacają rodzimy system, a także przyczyniają się do jego zmiany ${ }^{37}$. Przykładem takich procesów jest celebrowanie przez Polaków zapożyczonych świąt, jak Walentynki czy Helloween. Otwartość Polski na odmienne kultury wzbogaca możliwość wyboru przez Polaków filmów, sztuk teatralnych, książek, muzyki czy, w bardziej pragmatycznym podejściu, kuchni i trendów w modzie, które mają w sobie elementy stygmatyzujące różne kręgi kulturowe. Polacy mają także wybór stylu życia, który najbardziej koresponduje z ich oczekiwaniami i spodziewanymi rezultatami - życie prywatne, mobilność zawodowa, konsumpcja. Zaakceptowali także nową wizualizację przestrzeni, w której nierzadkie są symbole McDonalda, KFC, Forda czy Mercedesa ${ }^{38}$. Z drugiej strony, do uniwersalnego systemu kultury przenikają elementy rodzimej historii czy tradycji. Przykładem są chociażby nagrody dla polskich produkcji filmowych - Oskar dla Idy ${ }^{39}$ czy Międzynarodowa Nagroda Bookera 2018 dla Olgi Tokarczuk za książkę Bieguni ${ }^{40}$. Twórcy polskiej kultury zyskują światowy rozgłos, a polskie wynalazki są opisywane w najlepszych czasopismach naukowych. Polacy w tej samej chwili, co inne społeczeństwa otrzymują nowe wytwory kultury zarówno tej użytkowej, jak i duchowej. To wszystko ubogaca Polskę dzięki jej miejscu w systemie światowym. Z drugiej strony musimy pamiętać, że niektórzy wyrażają obawy, iż przedostawanie się do Polski odmiennych od rodzimej kultur może zagrozić naszej tożsamości narodowej i utrwalonemu przez stulecia systemowi kultury.

Rodacy w poważnym stopniu akceptują wydarzenia będące manifestacją odmiennych od polskiej kultur etnicznych czy narodowych. Festiwal Kultury Romskiej czy Żydowskiej są doskonałym przykładem, a liczne w nich uczestnictwo Polaków potwierdza ich atrakcyjność i przyzwolenie na obecność w polskim społeczeństwie. Nie należy jednak przyjmować a priori, że każda odmienność kulturowa jest dzisiaj przez Polaków akceptowana. Sprzeciw mieszkańców stoli-

${ }^{37}$ D. BRZEZIŃSKI, Redukcja i proliferacja, s. 38.

${ }^{38}$ G. RITZER, Mcdonaldyzacja społeczeństwa, tłum. S. Magala, Warszawa: Warszawskie Wydawnictwo Literackie MUZA SA 1999.

${ }^{39}$ Film „Ida” w reżyserii Pawła Pawlikowskiego otrzymał Oskara za najlepszy film nieanglojęzyczny 2014.

${ }^{40}$ O. ToKarCZuK, Bieguni, Kraków: Wydawnictwo Literackie 2018. 
cy, i nie tylko, wobec budowy Centrum Kultury Muzułmańskiej na warszawskiej Ochocie jest przykładem postawy odrzucenia i niegodzenia się Polaków na wprowadzanie elementów odmiennych kultur w pejzaż współczesnej Polski. Pomimo tego Polacy coraz częściej są świadkami wkomponowywania symboli rozmaitych kultur w kształtujący się obraz współczesnej Rzeczpospolitej. Mamy przecież pięć wolno stających w Polsce meczetów, które gromadzą miejscowych muzułmanów na modlitwę. W obrazie Polski jest także 27 synagog, pełniących funkcje reprezentacyjne miejscowych gmin żydowskich. Nabożeństwa w nich odbywają się tylko w najważniejsze święta. Wydaje się równocześnie, że większe przyzwolenie Polacy wyrażają wobec odmiennych elementów należących do rozmaitych kultur materialnych. Oznacza to, że Polska wykazuje przychylność wobec zjawiska, które Stanley Fish określił jako butikowy multikulturalizm (boutique multiculturalism). Charakteryzuje się on pobieżnym czy kosmetycznym przywiązaniem do przedmiotu tradycji odmiennej od innych ${ }^{41}$. W codziennym życiu oznacza to proste nasycenie przestrzeni społecznej symbolami, identyfikującymi kulturowe zróżnicowanie. Chodzi o popularne etniczne restauracje, festiwale i imprezy, które w sposób nader prosty manifestują kulturową inność ${ }^{42}$. Polacy coraz chętniej korzystają z kuchni świata, chociaż równie często powracają do tradycyjnej kuchni polskiej. Jest to folkloryzm globalny, który coraz silniej kształtuje styl naszego życia. Dzisiaj, w każdym niemal zakątku świata, a więc także i w Polsce, możemy skorzystać z sieci znanych światowych restauracji, skorzystać z ulubionego hotelu czy kupić buty, ubrania, samochód znanej światowej marki. Produkty różnych kultur są dostępne wszędzie, a równocześnie koloryzują ulice światowych, europejskich i polskich miast. W Polsce dobrą przestrzenią tego procesu jest Warszawa, chociaż nie tylko, gdzie najliczniej zgromadzili się nowi, najczęściej czasowi, imigranci wnoszący wszystkie wymienione odmienności do polskiej codzienności. Stanowią one spektakularne elementy współczesnej kultury Polaków, akceptowane przez jednych, ale odrzucane przez innych. Taka jest dzisiejsza kultura polska, która pozostaje dynamiczna, gdyż wymaga tego współczesny system światowy, którego Rzeczpospolita jest elementem.

${ }^{41}$ S. Fish, Boutique Multiculturalism, or Why Liberale Are Incapable of Thinking about Hale Speech, "Critical Inquiry" 1997, Vol. 23, No 2, s. 378-395, http://www.jstor.org/stable/1343988 [dostęp: 28.09.2015]; W.J. BurszTA, Świat jako więzienie kultury. Pomyślenia, Warszawa: PIW 2008, s. 69.

${ }^{42}$ S. Fish, Boutigue, s. 378-395. 


\section{ZAKOŃCZENIE, CZYLI POLSKA W KULTURZE GLOBALNEJ}

Współczesna Polska podlega wypracowanym przez świat regułom zarówno w zakresie ekonomii, polityki, jak i kultury. Respektuje zasady kultury odpolitycznionej kształtowanej przez rynek - supermarket kultury, jak nazywa ją Gordon Mathews, który powiada: „Kultury [...] są jak potrawy na stole. Po prostu bierzesz to co chcesz. W ten sposób kulturę moglibyśmy zdefiniować jako informacje i tożsamości dostępne w globalnym supermarkecie kultury" ${ }^{43}$. W dzisiejszym świecie globalnej i wzmożonej migracji ludzi, kapitału i idei kulturę trudno wyobrazić sobie jako coś, co łączy ludzi w konkretnym miejscu na Ziemi, przeciwstawiając ich zarazem ludziom zamieszkującym inne miejsca. Ludzkość widzi przecinające świat kultury, a nie ich odrębność symbolizowaną jasno określonymi granicami ${ }^{44}$. Dzisiaj trudno mówić o kulturze amerykańskiej, francuskiej, polskiej czy każdej innej, która kształtowana była wyłącznie przez określony naród. Współczesny świat to właśnie metaforyczny supermarket, w którym znajdujemy towary pochodzące $\mathrm{z}$ różnych światów, zgromadzonych obok siebie w jednej przestrzeni. „Wszędzie jest chińskie jedzenie, chleb pita, muzyka country, pizza i jazz. Przenikanie form etnicznych do świata odzwierciedla kosmopolityzację tego, co specyficzne. [...] Globalizacja nie oznacza kresu poszczególnych fragmentów składowych. Przeciwnie, oznacza ich ekspansję do rozmiarów światowych" ${ }^{\prime 4}$. W takim właśnie supermarkecie kultury coraz bardziej żyją Polacy. To życie w świecie, który nie narzuca człowiekowi jednej wizji, ale jest to świat przede wszystkim ludzkich wyborów. Pięknie o takim świecie pisał Theodore H. Von Laue: „W świecie, w którym zbiegają się wszystkie kultury, religie oraz doświadczenia historyczne, zgromadzone przez tysiące lat, całe kulturowe dziedzictwo ludzkości znajduje się na widoku. [...] W wielkich metropoliach [...] rywalizują ze sobą religie i style życia pochodzące $\mathrm{z}$ różnych części świata. Świat stał się domem towarowym zapchanym bogactwami, które ludzkość wytworzyła. [...] Współczesne pokolenie to ludzie urodzeni, by kupować albo przynajmniej oglądać witryny w ogromnym supermarkecie świata, w którym wybór towarów stanowi wyzwanie i oszałamia kupującego"46. Taki świat od ponad trzech dekad coraz wyraźniej staje się normalnością i codziennością Polaków. W polskiej przestrzeni społeczno-kulturowej stykają się i przecinają różne

\footnotetext{
${ }^{43}$ G. MATHEws, Supermarket kultury, thum. E. Klekot, Warszawa: PIW 2005, s. 17.

${ }^{44}$ Tamże, s. 17.

${ }^{45}$ T. LevitT, The Marketing Imagination, New York: The Free Press 1983, s. 30-31.

46 T.H. Von Laue, The World Revolution of Westernization: The Twentieth Century in Global Perspective, New York: Oxford University Press 1987, s. 339.
} 
kultury. To tworzy rzeczywistość, w której świadomość różnorodności aksjologicznej i normatywnej kształtuje postawy Polaków. W dużym stopniu opierają się one na akceptacji bądź odrzuceniu nowych wzorów kulturowych. Ale przecież Polacy właśnie o taki świat walczyli przez ponad 40 lat od zakończenia II wojny światowej.

\section{BIBLIOGRAFIA}

Aktywność Polaków w organizacjach obywatelskich. Komunikat z badań CBOS, Warszawa, luty 2018.

BAUMAn Z.: Globalizacja. I co z tego dla ludzi wynika, tłum. E. Klekot, Warszawa: PIW 2000.

BAUMAN Z.: Szkice z teorii kultury, Warszawa: Wydawnictwo Naukowe Scholar 2017.

Bourdieu P., PAsSERon J.-C.: Reprodukcja. Elementy teorii systemu nauczania, tłum. E. Neyman, Warszawa: Wydawnictwo Naukowe PWN 2006.

BuRSZTA W.: Wielokulturowość. Pytania pierwsze, w: U progu wielokulturowości. Nowe oblicza społeczeństwa polskiego, red. M. Kempny, A. Kapciak, S. Łodziński, Warszawa: Oficyna Naukowa 1997.

BurszTA W.J.: Świat jako więzienie kultury. Pomyślenia, Warszawa: PIW 2008.

BRZEZIŃSKI D.: Redukcja i proliferacja wieloznaczności: teoria kultury Zygmunta Baumana w polskim okresie jego twórczości, „Studia Socjologiczne” 2017, nr 1(224), s. 29-57.

Custine De A.: Listy z Rosji. Rosja w 1839 roku, tłum. M. Leśniewska, Łódź: Editions Spotkania 2015.

CZYKwIN E.: Stygmat społeczny, Warszawa: Wydawnictwo Naukowe PWN 2007.

FloRIDA R.L.: Cities and the Creative Class, New York-London: Routledge 2005.

GeErtz C.: After the Fact. Two Countries, Four Decades, One Anthropologist, Cambridge, Mass.: Harvard University Press 1995.

Goffman E.: Piętno. Rozważania o zranionej tożsamości, tłum. A. Dzierżyński, J. Tokarska-Bakir, Gdańsk: Gdańskie Wydawnictwo Psychologiczne 2005.

JAŁOWIeCKi B., SzczepańSKi M.S.: Dziedzictwo polskich regionów, w: Jedna Polska? Dawne i nowe zróżnicowania społeczne, red. A. Kojder, Warszawa: WAM 2007.

JELONEK A.W., TYSZKA K.: Koncepcje rozwoju społecznego, Warszawa: Wydawnictwo Naukowe Scholar 2001.

KRZYSZTOFEK K., SZCZEPAŃSKi M.S.: Zrozumieć rozwój. Od społeczeństw tradycyjnych do informacyjnych, Katowice: Wydawnictwo Uniwersytetu Śląskiego 2005.

KymlickA W.: Multicultural Citizenship. A liberal Theory of Minority Rights, Oxford: Oxford University Press 1994 .

Laue Von T.H.: The World Revolution of Westernization: The Twentieth Century in Global Perspective, New York: Oxford University Press 1987.

LASKOWSKA I., DAŃSKA-BORSIAK B.: Analiza przestrzennego zróżnicowania rozwoju społecznego w Polsce na poziomie NUTS 3 z wykorzystaniem lokalnego indeksu HDI, „Acta Universitatis Lodziensis", Folia Oeconomica 2018, nr 1(333), s. 111-131.

LeRner D., SChramm W.: Communication and Change in Developing Countries; the last 10 years and next, Honolulu: University Press of Hawaii 1976.

LeVitT T.: The Marketing Imagination, New York: The Free Press 1983.

MATHEws G.: Supermarket kultury, tłum. E. Klekot, Warszawa: PIW 2005. 
RITZER G.: Mcdonaldyzacja społeczeństwa, tłum. S. Magala, Warszawa: Warszawskie Wydawnictwo Literackie MUZA SA 1999.

SADOWSKI A.: Pochodzenie etniczne a tożsamości narodowe. Narody pluralistyczne na przykładzie Europy Środkowo-Wschodniej, „Kultura i Społeczeństwo” 62(2018), nr 2, s. 135-153.

SADOWSKI A.: Zróżnicowanie kulturowe a społeczeństwo obywatelskie, „Sprawy Narodowościowe" 1999, nr 14-15.

SLANY K.: Alternatywne formy życia małżeńsko-rodzinnego w ponowoczesnym świecie, Kraków: Zakład Wydawniczy Nomos 2002.

SzCZePański M.S.: Pokusy nowoczesności. Polskie dylematy rozwojowe, Kraków-Katowice: Amp 1992.

SzCZEPAŃSKI M.S.: W europejskiej poczekalni, „Studia Europejskie” 1999, nr 4, s. 11-30.

Socjologia regionu i społeczności lokalnych. Antologia, red. M.S. Szczepański [i in.], Opole: Wydawnictwo Uniwersytetu Opolskiego 2011.

SZCZEPAŃSKI M.S., ŚLIZ A.: WieloPolska: nowe struktury - nowe zróżnicowania, Warszawa: Wydawnictwo Naukowe PWN 2012.

TOKARCZUK O.: Bieguni, Kraków: Wydawnictwo Literackie 2018.

WiLKOSZEWSKA K.: Ku estetyce transkulturowej. Wprowadzenie, w: Estetyka trnaskulturowa, red. K. Wilkoszewska, Kraków: Universitas 2004.

\section{ŹRÓDŁA INTERNETOWE}

FISH S.: Boutique Multiculturalism, or Why Liberale Are Incapable of Thinking about Hale Speech, "Critical Inquiry” 1997, Vol. 23, No. 2; http://www.jstor.org/stable/1343988

Wyznania w Polsce, http://www.wsp.krakow.pl/apismo/nr1/01/wyznania.html [dostęp: 17.03.2009].

Narodowy Spis Powszechny Ludności i Mieszkań 2011, www.stat.gov.pl [dostęp: 14.09.2015].

Ustawa z dnia 6 stycznia 2005 r. o mniejszościach narodowych $i$ etnicznych oraz o języku regionalnym, Dz.U. 2005, Nr 17, poz. 141; Dz.U. 2005, Nr 64, poz. 550, http://e-prawnik.pl/ kodeksy/ustawy/ustawa-o-mniejszościach-narodowych... [dostęp: 14.09.2015].

www.agenda21.waw.pl [dostęp: 30.12.2010].

Mniejszości etniczne w Polsce [Infografika], https://wiadomosci.onet.pl/kraj/mniejszosci-etnicznew-polsce/f2x3jx5 [dostęp: 26.03.2019].

Doskonały wynik Polski. Nasza gospodarka w 2018 roku przyśpieszyła, ale są rysy na szkle: https://businessinsider.com.pl [dostęp: 24.03.2019].

Gonimy Unię, ale powoli. Poziom PKB na mieszkańca Polski zwiększył się do 11,8 tys. euro: https://www.money.pl [dostęp: 25.03.2019].

PKB polskich województw w zestawieniu ze średnią UE: https://www.rp.pl [dostęp: 25.03.2019].

Human Development Reports: hdr.undp.org/en/2018_update [dostęp: 25.03.2019].

Polska awansowała do grupy 25 krajów najbardziej rozwiniętych na świecie: https://www.polish express.co.uk [dostęp: 26.03.2019].

https://stat.gov.pl/podstawowe_dane/ [dostęp: 25.03.2019]. 


\section{KULTUROWE DYLEMATY POLSKIEJ TRANSFORMACJI: MIĘDZY ADAPTACJĄ A ODRZUCENIEM}

\section{Streszczenie}

Współczesny świat uwikłany jest w procesy o znaczeniu globalnym. Najważniejsze to globalizacja i metropolizacja, których rezultaty zmieniają polski system ekonomiczny, polityczny i kulturowy. Głównym celem artykułu jest pokazanie zmian, jakie zaszły w polskiej kulturze po 1989 r. Po pierwsze, Polska stała się społeczeństwem zróżnicowanym kulturowo, gdyż żyją tutaj mniejszości etniczne, narodowe czy religijne. Po drugie, do Polski docierają elementy innych kultur, ale także elementy polskiej kultury stały się uniwersalne. To wszystko się dzieje, gdyż Polska została włączona w system światowy.

Słowa kluczowe: kultura; transformacja; zróżnicowanie kulturowe; system światowy

\section{CULTURAL DILEMMAS OF POLISH TRANSFORMATION: BETWEEN ACCEPTANCE AND REJECTION}

\section{S u m m ary}

Today's world is undergoing a lot of processes of global significance. The most important of global processes are globalization and metropolization causing system of Polish economic, political and cultural change. In this article the main objective is to show changes in Polish culture after 1989. On the one hand, Poland has become the society of cultural diversity because ethnic, national and religious minorities living here. On the other hand, the elements of different cultures are brought to Poland and Polish elements of culture become universal. All the situations happen because Poland became part of the world system in 1989.

Key words: culture; transformation; cultural diversity; world system 